\title{
THE EFFECTIVENESS OF CORRECTIVE FEEDBACK TO THE STUDENTS' GRAMMATICAL CONSTRUCTION ON PARAGRAPH WRITING CLASS
}

\author{
Dina Merris Maya Sari \\ STKIP PGRI Sidoarjo \\ merris_dina1@gmail.com
}

\begin{abstract}
Writing is one of the most important skills to mastery English. But there are many students get difficulties in writing. They worried when they make errors in their writing. To overcome this problem, the researcher uses corrective feedback. Here, corrective feedback is used to revise the students' writing. The students can revise their writing in a correct and better one. Based on the reason above, the objective of the study is "to know the effectiveness of using corrective feedback in paragraph writing class". This research is experimental research and the researcher uses quantitative research. There are two groups of students participated in the study, control group and experimental group. The subject of this research is 24 students of first semester at English Education Department. The researcher tested the students' writing composition to collect the data. T-test calculated on SPSS Statistic 17.0, it is to find out the differences between students' pretest and posttest scores of experimental and control group. This result show that the experimental group which is taught by using corrective feedback get high scores than the control group which is not taught by using corrective feedback.
\end{abstract}

Keywords: Corrective Feedback, Paragraph Writing

\section{INTRODUCTION}

Writing has always been regarded an important skill contributing to students' language learning. However, for many learners of English as foreign language, writing is considered the most difficult skill to acquire because it requires having a certain amount of L2 background knowledge about rhetorical organization, appropriate language use or specific lexicon with which they want to communicate their ideas (Ahmadi, Maftoon, \& Mehrdad, 2012). Harmer (2004) says that the reasons for teaching writing to students of English as a foreign language are for reinforcement, language development, learning style and most importantly as a basic skill. Some teachers find that their students are not enthusiastic in learning how to write paragraph or composition in English. While the students feel that writing is difficult subject tolerant. Moreover, they feel difficult to create ideas and express their ideas into writing.

According to Russilawatie (2005), "Writing is a skill which an academic person must have". That is why the students have to learn writing in English well. In other hand, writing only learn at formal institute (such as school, college or course) and it is rarely used in daily life, so the writing is difficult activity and learning to write should be practiced frequently. Nunan (2003) views writing in two approaches, they are process and product approach. The product approach focuses on the final product, the coherent, and the error-free text. It means the teacher only scores his students' final composition, or essay, letter, story or even research report that she colllects from her students. On the other hand, process approach focuses on the steps involved 
in drafting, redrafting a piece of work. The process of writing begins with the imagination of the student-writer then continues when he starts to organize, makes draft until he finishes his composition.

Here, we can see that writing is also important skill which has to be learned besides the other skills. The students of university are obliged to learn writing skill. Related to the notion of genre for university, the students in university have to learn some steps of writing such as,paragraph writing, essay writing, argumentative writing and scientific writing. Unfortunately, many students of university are not good yet in writing. Students are often getting difficulties to write the target language, because they can't write such simple composition in the writing class because they are confuse to express their ideas to organize the text well, and they feel afraid to make grammatical mistakes that they usually faced.

By knowing the condition of the students of university who learn English as foreign language, the researcher tends to choose the appropriate technique that will produce good result in teaching writing. The alternative technique is called corrective feedback, which is by sending back the response of giving correction.

Referring to the background of the study, there is statement of problem that should be taken into consideration "Do students who are taught paragraph writing using corective feedback get higher achievement than those who are taught paragraphwriting without using corrective feedback?". Based on the statements of the problem stated above, the objective of the study is "To know the effectiveness of using corrective feedback technique in teaching paragraph writing".

Feedback is constant when it is provided to the learners at regular, frequent intervals over an extended period of weeks or months. Finally, writing tasks and feedback need to be manageable. Teachers need enough time to provide quality feedback and students need enough time to process and apply the feedback they receive. Too much feedback could undermine efforts to keep feedback meaningful, timely, and constant(Evans, Hartshorn, \& Strong-Krause, 2011). Providing feedback to students, whether in the form of written commentary, error correction, teacher-student conferencing, or peer discussion, has come to be recognized as one of EFL writing teacher's more important tasks, offering the kind of individualized attention that is otherwise rarely possible under normal classroom conditions (Yilmaz, 2009)

In the case of corrective feedback, there are direct feedback and indirect feedback.In direct feedback, the students are provided with the correct form, the teachers cross out an unnecessary word, insert a missing word, and write the correct form. This type of feedback is desirable for low-level-of proficiency students who are unable to self-correct, and can not 
provide the correct form (Ellis, 2009). However, Sheen (2007) indicates that direct corrective feedback can be beneficial for learning only some specific grammatical features. Indirect feedback occurs when the students are informed in some way that an error exists but are not provided with the correct form, thus placing the burden of spotting the erroneous forms on students. The experts in the field argue that indirect feedback is superior for most students, because it involves them in guided learning and problem solving (Maleki \& Eslami, 2013).

Corrective feedback is used in writing classes of both first language and second language to provide students more opportunities to learn from each other. After students finish a writing assignment, the teacher give correction for the students.Corrective feedback can be in the form of corrections, opinions, suggestions, ideas to each other. Instead of focusing on the surface-level mechanics and grammatical correctness in product-oriented approach, writing is viewed as "A complex development task" in the light of process approach. Therefore, processoriented feedback should focus on both meaning and form. As Rollinson (2005) concluded that teacher's feedback in writing has high value to the students and there are many teachers have used this kind of feedback in writing especially in written feedback. Corrective feedback also occured by peer students itself. According to Atay and Kurt (2007), in peer feedback session, students do not just listen to teacher' instructions, but work with their peers to do more practices in writing. In this case, students' anxiety becomes lower and learning motivation can be higher.

From those ideas above, it can be concluded that corrective feedback is one of the excellent techniques in teaching writing. It assists students for editing, commonly in rewriting process. It allows them to revise their ideas. It also can enhance their composition by changing the grammatical, mechanical errors, inappropriate organizational and content errors into the correct and appropriate ones.

\section{METHOD}

This research is an experimental research. The researcher used the experimental quantitative research, because it is a scientific investigation in which a manipulation on dependent variable. The spesific type of experimental research in this research is quasiexperimental research that is a powerful research method to establish cause and effect relationship. The design of quasi-experimental type is the pre test-post test non equivalentgroups design. The design employs two groups, experimental group and the control one. The experimental group is the group where the treatment implemented. They are subjected to the use of corrective feedback in teaching paragraph writing while the control group is subjected without using corrective feedback. These two groups are given the same materials and written test. To measure the difference of the student's writing ability between the two groups, a pre test 
and post test are administrated. The pre test is giving at the beginning of the study in order to know the student's writing ability before the treatment and the post test is offered later at the end of the treatment to both experimental and control group. The design of the research is illustrated as follows:

Table 1

Design of The Research

\begin{tabular}{|c|c|c|c|}
\hline Group & $\begin{array}{c}\text { Pre- } \\
\text { Test }\end{array}$ & Treatment & $\begin{array}{c}\text { Post- } \\
\text { Test }\end{array}$ \\
\hline 1 & Y1 & $\mathrm{X}$ & $\mathrm{Y} 2$ \\
\hline 2 & $\mathrm{Y} 1$ & - & $\mathrm{Y} 2$ \\
\hline
\end{tabular}

Note:

1 : Experimental Group

2 : Control Group

Y1: Pre-test

Y2: Post-test

$\mathrm{X}$ : Independent Variable

There are two variables measured in this experiment or research. They are independent variable and dependent variable. The independent variable is the variable that comes first and influences or predicts the result. And the dependent variable is affected and predicted by the independent variable (Millan, 1992). In this research, the independent variable is corrective feedback, while the dependent variable is students' writing ability.

The test can be called valid if it measures internal knowledge or measures what should be measured. Based on the testing of validity, Arikunto(2002) divides validity into two types; external validity and internal validity. External validity is the validity which is achieved when the data collected by the instruments are appropriate with the data. It is measured using the formula of Cronbach's alpha on SPSS 17.0. Whereas the internal validity is the validity which is achieved by analyzing factors and items.

Reliability is a necessary characteristic of any good test for it to be valid at all: a test must be reliable first, as a measuring instrument. If a measure has high reliability, it has relatively little error. Reliability can be meant as the stability of at a test score. It means that a test would have high reliability if it gives consistent result. To establish the reliability of the test used by the researcher as a instrument, the researcher uses the formula of Cronbach's alpha SPSS 17.0, since it required a single administration of test.

To analyze the data, after collecting the data of pretest and posttest from the experimental group and control group. The next step is finding out the difference score between pretest and posttest of each group. Then, it is analyzed by using calculation t-test to find out 
whether or not the difference between them is significant. Next, the researcher used t-test to analyze the pretest scores both experimental group and control group, and then it is continued with analyze the posttest scrores both of them. The last, the researcher used t-test to analyzed the significance different between pretest and posttest to both experimental group and contol group.

All of the calculation are done by using SPSS Statistic 17.0, a computer program for statistical calculation. In here, the researcher used Independent Sample Test and Paired Sample t-test. The researcher used independent sample test to know the difference students' score in pretest of the experimental and the control group, and to know difference students' score in posttest of the experimental and the control group. She also used paired sample t-test because want to know difference students' value in pretest (before treatment) and students' value in posttest (after treatment). Finally, from the result of t-test, the researcher knows the effectiveness of corrective feedback technique by the significant of pretest and posttest between the students who are taught by corrective feedback technique and who are not taught by corrective feedback technique.

\section{FINDING AND DISCUSSION}

This research is conducted to find out the effectiveness of using corrective feedback in teaching paragraphwriting. The subject of the research are two classes, they are experimental group and control group. The researcher conducted the experiment (pretest, treatment, and posttest), and the control (pretest and posttest). The data from the students' test is included in the data computation.

The computation result is done using the analysis of t-test run in SPSS Statistic 17.0. The data are collected from students' pretest and posttest scores. The pretest was administered before the treatment, while the posttest is administered after treatments to the experimental group and after teaching without applying the treatment to the control group. Thus, there are two scores of pretest and posttest.

There are some steps to analyze the data of the study. First, the researcher tests the reliability of the pre-test questions before give it to the students. The result of the reliability test shown in the tabel below :

Table 2

The result of reliability test

\begin{tabular}{|l|lr|}
\hline \multicolumn{2}{|c|}{ Reliability Statistics } \\
\hline Cronbach's Alpha & \multicolumn{1}{|c|}{ N of Items } \\
\hline
\end{tabular}


From the data above, it can be concluded that the result of reliability test is 0.749 . The reliability test is high. "If $\alpha>0.6$ it shows the excellent internal consistency reliability" (Azwar, 2001). If a measure has high reliability, it has relatively little error. Reliability can be meant as the stability of a test score. It means that a test would have high reliability if it gives a consistent result.

Second, the researcher tests the validity of the pre-test questions before give it to the students. The result of the validity test shown in the tabel below:

Table 3

The result of validity test

\begin{tabular}{|l|r|r|r|r|}
\hline \multicolumn{7}{|c|}{ Item-Total Statistics } \\
\hline & $\begin{array}{c}\text { Scale Mean if Item } \\
\text { Deleted }\end{array}$ & $\begin{array}{c}\text { Scale Variance if } \\
\text { Item Deleted }\end{array}$ & $\begin{array}{c}\text { Corrected Item-Total } \\
\text { Correlation }\end{array}$ & $\begin{array}{c}\text { Cronbach's Alpha if } \\
\text { Item Deleted }\end{array}$ \\
\hline X1.1 & 60.63 & 122.914 & .831 & .731 \\
\hline X1.2 & 61.42 & 128.790 & .382 & .746 \\
\hline X1.3 & 61.55 & 127.709 & .409 & .743 \\
\hline X1.4 & 61.58 & 127.230 & .441 & .742 \\
\hline X2.1 & 59.85 & 122.672 & .588 & .732 \\
\hline X2.2 & 61.58 & 126.315 & .529 & .740 \\
\hline X2.3 & 61.67 & 127.480 & .398 & .743 \\
\hline X3.1 & 59.05 & 121.065 & .580 & .729 \\
\hline X3.2 & 59.03 & 120.880 & .570 & .729 \\
\hline X3.3 & 57.88 & 119.054 & .612 & .725 \\
\hline X4.1 & 58.35 & 123.282 & .639 & .733 \\
\hline X4.2 & 58.48 & 119.576 & .826 & .723 \\
\hline X4.3 & 46.42 & 76.145 & .566 & .744 \\
\hline X4.4 & 58.75 & 121.919 & .506 & .732 \\
\hline X5 & 45.25 & 73.208 & .565 & .756 \\
\hline
\end{tabular}

From the data above, it can be seen that the validity from all of questions' item are more than 0.3 . The validity of the test have range mark $r=0.382$ until $r=0.831$. "If $r>0.3$ it shows the excellent internal consistency validity" (Azwar, 2001). So it can be concluded that the tests are valid.

In this chapter, the researcher only present the result of the calculation of the mean and t-test (Independent Sample T-test) of pretest and posttest scores of the control and experimental group are presented in the following Table:

Table 4

Independent Sample Test

\begin{tabular}{|c|c|c|c|c|c|}
\hline \multicolumn{6}{|c|}{ Group Statistics } \\
\hline & $\begin{array}{l}\text { Group } \\
\text { Research }\end{array}$ & $\mathrm{N}$ & Mean & Std. Deviation & Std. Error Mean \\
\hline Pretest Score & 1 & 30 & 63.67 & 10.597 & 1.935 \\
\hline
\end{tabular}




\begin{tabular}{|l|l|r|r|r|r|}
\hline & 2 & 30 & 60.83 & 12.349 & 2.255 \\
\hline Posttest Score & 1 & 30 & 75.50 & 8.669 & 1.583 \\
\cline { 2 - 6 } & 2 & 30 & 60.87 & 11.190 & 2.043 \\
\hline \multirow{2}{*}{ Gain Score } & 1 & 30 & 12.20 & 6.105 & 1.115 \\
\cline { 2 - 6 } & 2 & 30 & .03 & 2.553 & .466 \\
\hline
\end{tabular}

Table 4 shows the mean ofthe pretest and posttest scores of the control and the experimental group. The mean pretest score is 63.67 for the experimental group and 60.83 for the control group. It can be seen that the mean of the control group is lower than the mean of the experimental group. The Table also shows that the mean of the posttest score is 75.50 for the experimental group and 60.87 for the control group. It can be seen that the mean of posttest of the experimental group is higher than that of the control group.

Then, the researcher calculates the mean of pretest and posttest scores of the experimental and the control group by using t-test (Paired sample test) to know whether or not the scores before giving the treatment and after giving the treatment is significant. The result is presented in the following Table:

Table 5

Paired Sample Test

\begin{tabular}{|c|c|c|c|c|c|c|c|c|c|}
\hline \multicolumn{10}{|c|}{ Paired Samples Test } \\
\hline & & \multicolumn{5}{|c|}{ Paired Differences } & \multirow[b]{3}{*}{$\mathrm{T}$} & \multirow[b]{3}{*}{ Df } & \multirow[b]{3}{*}{$\begin{array}{l}\text { Sig. (2- } \\
\text { Tailed) }\end{array}$} \\
\hline & & & & & \multicolumn{2}{|c|}{$\begin{array}{c}\text { 95\% Confidence } \\
\text { Interval Of The } \\
\text { Difference }\end{array}$} & & & \\
\hline & & Mean & $\begin{array}{c}\text { Std. } \\
\text { Deviation }\end{array}$ & $\begin{array}{l}\text { Std. } \\
\text { Error } \\
\text { Mean }\end{array}$ & Lower & Upper & & & \\
\hline \begin{tabular}{l|} 
Pair \\
1
\end{tabular} & \begin{tabular}{|l|} 
Posttest \\
Control - \\
Pretest \\
Control \\
\end{tabular} & .033 & 2.553 & .466 & -.920 & .987 & .072 & 29 & .943 \\
\hline $\begin{array}{l}\text { Pair } \\
2 \\
\end{array}$ & \begin{tabular}{|l} 
Posttest \\
Experiment \\
- Pretest \\
Experiment
\end{tabular} & 11.833 & 6.808 & 1.243 & 9.291 & 14.376 & 9.520 & 29 & .000 \\
\hline
\end{tabular}

From the calculation of $\mathrm{t}$-test, it is found that $\mathrm{t}$-value of the experimental group is 1.243 with 58 degrees of freedom and 5\% level of significance. Meanwhile the t-Table is 0.29 . It is shows that the result of the pretest and posttest calculation of the experimental experimental group is higher than t-Table. It means that the difference in pretest and posttest score of the experimental group is significant. From the calculation of t-test, it is also found that $t$-value of the control group is 0.466 with 58 degrees of freedom at $5 \%$ level of significance with the $t$ Table 0.29. It shows that the result of pretest and posttest calculation of the control group is 
higher than t-table. It means that the difference is significant. Although the differences of both group are significant, the difference of the experimental group is much bigger than the control group.

In this part, the purpose is to investigate whether the corrective feedback can be effective to teach students' paragraph writing by finding out whether or not there is significant difference between pretest and posttest scores of the experimental and the control group. The result is presented in the Table below:

Table 6

The difference between pretest and posttest of the experimental and the control group

\begin{tabular}{|l|r|r|r|}
\hline \multicolumn{3}{|c|}{ Descriptive Statistics } \\
\hline Dependent Variable:Posttest Score \\
\hline Group Research & Mean & Std. Deviation & N \\
\hline 1 & 75.50 & 8.669 & 25 \\
\hline 2 & 60.87 & 11.190 & 25 \\
\hline Total & 68.18 & 12.367 & 50 \\
\hline
\end{tabular}

The Table shows that the mean of difference between pretest and posttest score is 75.50 for the experimental group and 60.87 for the control group. It can be seen that the mean of experimental group is higher than that of the control group. Then, the researcher calculates the mean of the difference between pretest and posttest scores of the experimental and the control group by using t-test (Independents sample t-test) to know whether or not it is significant. It shows that difference between pretest and posttest scores of the experimental and the control group is significant.

The research question is answered based on the result how it interlinks to the related literature. The research question is regarding the effectiveness of corrective feedback as the treatment conducted to the experimental group.

From the calculation of $t$-test, is is found that $t$-value of the experimental group is 1.243 with 58 degrees of freedom at $5 \%$ level of significance and the t-Table is 0.29 . It shows that the result of pretest and pretest calculation of the experimental group is higher than t-Table. It means that the differerence is significant. From the calculation of t-test, it is also found that $\mathrm{t}$ value of the control group is 0.466 with 58 degrees of freedom at $5 \%$ level of significance and the t-Table is 0.29. It shows that the result of the pretest and posttest calculation of the control group is higher than t-Table. It means that the difference is significant. Although the diffrerences 
of both groups are significant, the difference of the experimental group is much bigger than the control group.

The reason why the experimental group gets much higher score in posttest because of the effect of the treatments. It is necessary to further analyze how these treatments might work to the students. From the result, it can be shown that the difference of the gain between pretest and posttest scores of the experimental and the control group is significant. From the test given after each teaching (with the treatment for the experimental group and without the treatment for the control group), it can be shown that the scores of the experimental group are higher than of the control group.

The treatments trained the students to revise and correction based on their teacher feedback. By giving feedback to the students' writing composition, the students enhanced their knowledge of second language unintentionally. First, the teacher identify errors on the students' writing composition, then give the alternative answer to correct it based on the corective feedback given by the teacher. The effect of doing this technique that the students will recognize the errors on their own writing because they can learn by their mistakes, so the students can develop their writing to get better writing composition. In other words, the students have obtained the error awareness then they can do the independent self monitoring through their composition.

Based on the explanation above, it is shown that there is significant difference of writing composition scores between the students who have been taught by using corrective feedback technique and the students who have not been taught by using corrective feedback technique. It means that corrective feedback technique is effective to help the students in their writing ability. In the second language context, the effectiveness of corrective feedback that focuses on error correction is seen as particularly important, and the question of whether such corrective feedback is benefical to students' development (Hynland \& Fiona, 2006). So, it can be concluded that corrective feedback technique is effective in teaching paragraphwriting.

\section{CONCLUSION}

Based on the result of the study, it can be concluded that there is significant difference between the students who are taught by using corective feedback as the experimental group and the students who are not taught by using corrective feedback. The researcher uses the result of the statistical computation of t-test calculated by SPSS Statistics 17.0. from the distribution of $t$ table with the level of significance $5 \%$ it is found that the result of t-value is higher than the $t$ table with the degrees of freedom of 30 . 
From the results, the hypothesis, which says that corective feedback is effective in teaching paragraph writing, is accepted.

\section{REFERENCES}

Ahmadi, D., Maftoon, P., \& Mehrdad, A. G. (2012). Investagating The Effects of Two Types of Feedback on EFL Students' Writing. Procedia - Social and Behavioral Sciences, 25902595.

Arikunto, S. (2002). Prosedur Penelitian. Yogyakarta: Rineka Cipta.

Atay, D., \& Kurt, G. (2007). The Effects of Peer Feedback on The Writing Anxiety of Prospective Turkish Teachers of EFL. Journal of Theory and Practice in Education, $3(1), 12-23$.

Azwar, S. (2001). Reliabilitas dan Validitas. Yogyakarta: Pustaka Pelajar.

Ellis, R. (2009). A Typology of Written Corrective Feedback Types. ELT Journal, 63, 97-107.

Evans, N. W., Hartshorn, K. J., \& Strong-Krause, D. (2011). The Efficacy of Dynamic Written Corrective Feedback for University Matriculated ESL Learners. System 39, 229-239.

Harmer, J. (2004). How to Teach Writing. England: Longman.

Hynland, K., \& Fiona, H. (2006). Feedback in Second Language Writing. London: University of London.

Maleki, A., \& Eslami, E. (2013, July). The Effects of Written Corrective Feedback Techniques on EFL Students' Control over Grammatical Construction of Their Written English. Theory and Practice in Language Studies, 3(7), 1250-1257.

Millan, J. H. (1992). Educational Research, Fundamental for The Consumer. Virginia: Harper Collins Publisher.

Nunan, D. (2003). Practical English Language Teaching. Singapore: Mc Graw Hill.

Rollinson, P. (2005). Using Peer Feedback in The ESL Writing Class. ELT Journal, 59.

Russilawatie, N. (2005). Language and Culture Study. Journal on Literature, 3(2), 89-159.

Sheen, Y. (2007). The Effect of Focused Written Corrective Feedback and language Aptitude on ASL Learners' Acquuisition of Articles. TESOL Quarterly, 41, 255-283.

Yilmaz, K. (2009). Primary School Teachers Views About Pupil Control Ideologies and Classroom Management Styles. Cypriot Journal of Educational Sciences, 4(3), 157167. 